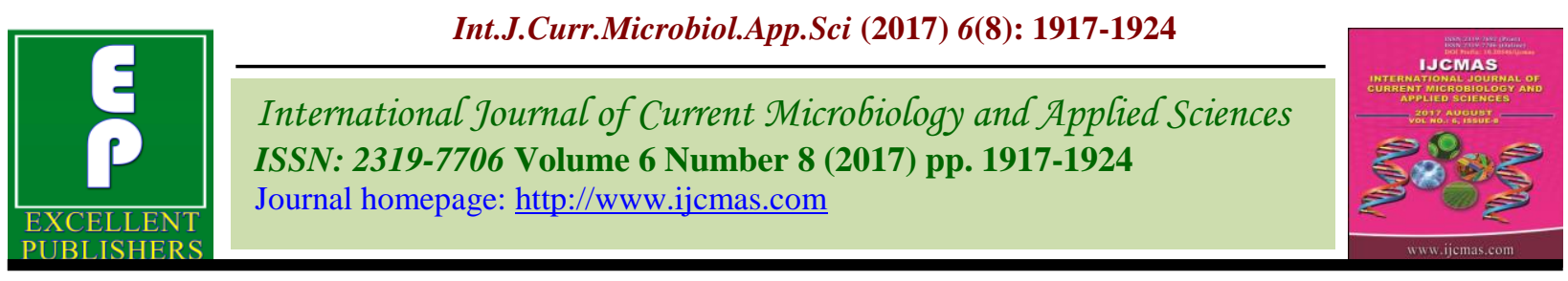

Review Article

https://doi.org/10.20546/ijcmas.2017.608.226

\title{
Mechanisms and Strategies for Improving Salinity Tolerance in Fruit Crops
}

\author{
Anjali Soni ${ }^{1 *}$, Sunita Dhakar ${ }^{2}$ and Neeraj Kumar ${ }^{3}$ \\ ${ }^{1}$ Division of Fruits and Horticultural Technology, ${ }^{2}$ Division of Floriculture and Landscaping, \\ ${ }^{3}$ Division of Genetics, ICAR- Indian Agricultural Research Institute, New Delhi 110 012, India \\ *Corresponding author
}

Keywords

Climate change,

Abiotic stress,

Salinity tolerance,

Strategies

Article Info

Accepted:

19 June 2017

Available Online:

10 August 2017

\section{A B S T R A C T}

Fruit trees can be potentially exposed to numerous abiotic stresses during production and distribution. Among these, salinity is one of the most important abiotic stresses, limiting crop production mainly in arid and semi-arid regions, where soil salt content is naturally high and precipitation can be insufficient for leaching (Zhao et al., 2007). According to the FAO Land and Nutrition Management Service (2008), over 6\% of the world's land is affected by either salinity or sodicity. Fruit crops are generally sensitive to salinity and sodicity. However, some fruit crops like pomegranate, sapota, aonla, bael, jamun, karonda, tamarind and date palms are relatively tolerant to salinity. Multiple solutions are available for managing these soils and enhance the productivity of horticultural crops in these soils. There is a need for an increased understanding of the mechanisms of salt tolerance, the development of methods to comprehensively integrate and predict the effects of environmental factors on plant response throughout all stages of growth and development, and the development of improved methods to identify and manipulate genes and gene groups between species.

\section{Salinity}

Salinity is the presence of excess soluble salt in the soil and one of the most significant environmental challenges limiting plant productivity, particularly in arid and semi-arid climates (Ashraf et al., 2004; Hussain et al., 2009). Salinity in irrigation water and in soils is one of the major abiotic constraints on agriculture worldwide causes reduction in growth and leaf scorching in fruit plants. As per ministry of Agriculture (GOI) In India, over 8.5 mha lands have been reported to be saline soil. Salt affected soils are found in Indo-Gangetic plains, arid regions and coastal areas. The malady continues to increase due to the mismanagement of canal irrigation as well as due to brackish groundwater irrigation. Salt damage usually manifests as leaf burn and defoliation, and is associated with accumulation of toxic levels of $\mathrm{Na}^{+}$and/or $\mathrm{Cl}^{-}$in leaf cells. The inhibition of crop growth under saline conditions is commonly caused by osmotic effect and/or due to excessive ion accumulation in the plant tissues, which may cause ionic toxicity and/or nutritional imbalance (Boursier and Lauchli, 1990). The extent to which each stress condition affects plant growth/development, however is dependent on various factors, 
including plant species, cultivar and phenological stage, soluble salt composition, stress intensity and its duration, and edaphoclimatic conditions (Cramer et al., 1994).

\section{Effect of Salinity on Fruit Plants}

The term 'salinity' refers to the presence in soil and water of electrolytic mineral solutes in concentrations that are harmful to many fruit crops. Salinity in soil or water is one of the major stresses and, especially in arid and semi-arid regions, can severely damage the fruit crop production. The deleterious effects of salinity on plant growth are associated with low osmotic potential of soil solution (water stress), nutritional imbalance, specific ion effect (salt stress), or a combination of these factors (Ashraf et al., 2004).

\section{General signs}

Plants on the basis of adaptive evolution can be classified roughly into two major types:

\section{Halophytes}

Halophytes are plants that can survive and reproduce in environments with high salt concentration $(200 \mathrm{mM} \mathrm{NaCl})$, these plants constitute about $1 \%$ of the world's flora. Halophytescan be classified as "natural" and plants that tolerate salt but do not normally live in saline conditions (Patane et al., 2012).

\section{Glycophytes}

The plants that cannot withstand salinity and eventually die. Majority of major fruit crop species belong to this category. Salinity is one of the most brutal environmental stresses that hamper fruit crops. The general signs of salinity include reduction in total leaf area, indeed, decreased leaf growth is the earliest response of glycophytes exposed to salt stress (Munns et al., 1986), marginal and tip burning of leaves, followed by yellowing and bronzing. In fruit plants premature leaf drop, twig dieback, leaf scorching, blackening, necrosis are the main symptom of salt stress. (Sharma et al., 2011).

Nutrient imbalance- Inhibition the uptake of essential nutrients like $\mathrm{K}^{+}, \mathrm{Ca}^{2+}$ leading to nutrient deficiency in fruit plants. The morphology of some fruit plants shows their sensitivity to salinity viz., in avocado trees, the root system is quite superficial and presents low ramification, thus reducing the water and nutrient absorption capacity, resulting in a higher sensitivity to soil salinity (Bernstien et al., 2005).

These morphological features limit the distribution of this crop to areas where irrigation water is of good quality. Another major effect is reduction in yield by decrease in fresh weight (FW) or dry weight (DW) in all plant tissues subjected to salt stress, but it is especially noticeable in the aerial part.

(Romero-Aranda et al., 1998) studied anatomical disturbances produced by chloride salts $\left(\mathrm{KCl}, \mathrm{ClCa}_{2}, \mathrm{NaCl}\right)$ in both sensitive (Carrizo citrange) and tolerant (Cleopatra mandarin) citrus varieties. The salt stress leads to changes in leaf anatomical properties, such as the increase in leaf thickness and the lower area/volume ratio of mesophyll cells. These results suggest that in salinized citrus, the increase in leaf thickness, in combination with several metabolic components such as chloride overloading, low $\mathrm{Mg}^{2+}$, stomatal closure and chlorophyll loss, may contribute, among other factors, to the decline in photosynthesis.

\section{Salinity tolerance mechanisms}

Under saline conditions, plants have to activate different mechanisms in order to cope with the resulting stress. Such mechanisms 
include changes in morphology, anatomy, water relations, photosynthesis, the hormonal profile, toxic ion distribution and biochemical adaptation (such as the antioxidative metabolism response).

\section{Salt avoidance}

Some fruit plants have the avoidance mechanism in which the reduction in the canopy area may be considered as an avoidance mechanism, which minimises water loss by transpiration when the stomata are closed.

\section{Salt exclusion}

Prevents the entry of salts into the vascular system. $\mathrm{Na}^{+}$and $\mathrm{Cl}^{-}$exclusion by roots ensures that $\mathrm{Na}^{+}$and $\mathrm{Cl}^{-}$does not accumulate to toxic concentrations in leaves.

\section{Salt excretion}

Halophytes can survive in the presence of high $\mathrm{NaCl}$ concentrations (300-500 $\mathrm{mM}$ ) because they have developed better salt resistance mechanisms viz. salt-secreting glands and hairs actively eliminate salts, thus keeping the salt concentration in the leaves beneath a certain threshold.

\section{Osmotic adjustment}

The osmotic adjustment, i.e., reduction of cellular osmotic potential by net solute accumulation, has been considered an important mechanism to salt and drought tolerance in plants. This reduction in osmotic potential in salt stressed plants can be a result of inorganic ion $\mathrm{Na}^{+}, \mathrm{Cl}^{-}$, and $\left.\mathrm{K}^{+}\right)$and compatible organic solute (soluble carbohydrates, amino acids, proline, betaines, etc) accumulations (Hasegawa et al., 2000). However these changes are only any few initial responses of many others occurred from salt-stressed seedlings. Likewise Higher salt tolerance due to higher capacity of osmotic adjustment (high proline) was found in Sour Orange and Attani-1 than Troyer citrange and Billikhichlli.

\section{Antioxidant defensive system}

Salinity tolerance is positively correlated with the activity of antioxidant enzymes, such as superoxide dismutase (SOD), catalase (CAT), glutathione peroxidise (GPX), ascorbate peroxidise (APX), and glutathione reductase (GR) and with the accumulation of nonenzymatic antioxidant compounds salt stress induces the increased activities of SOD, CAT, Ascorbate peroxidase and GR in Karna khatta having higher antioxidant capacity to $\mathrm{NaCl}$ (Sharma et al., 2011).

\section{Salinity tolerance strategies}

Salt tolerance is the ability of plants to grow and complete their life cycle on a substrate that contains high concentrations of soluble salt. Salt tolerance is a complex trait involving several interacting properties.

\section{Traditional approaches}

The deleterious effects of salinization can be managed by changed in farm management practices (Munns et al., 2002). Like better irrigation practices, such as drip irrigation, to optimize use of water can be employed. In rain-fed agriculture, this researcher suggest practices such as rotation of annual crops with deep-rooted perennial species may restore the balance between rainfall and water use, thus preventing rising water tables bringing salts to the surface. All such practices will rely on a high degree of salt tolerance, not only of the perennial species used to lower a saline water table, but also of the crops to follow, as some salt will remain in the soil. 


\section{Leaching}

Leaching excess salts and maintaining a favourable salt balance remains the best strategy to prevent detrimental salt accumulation in the soil profile. This is achieved by supplying enough water to leach salts below the root zone but not into ground water reserves. Irrigation water quality can have a profound impact on crop production. In reference, the work affirms that all irrigation water contains dissolved mineral salts, but the levels and composition of the salts vary depending on the source of the irrigation water. Salinity from irrigation can occur over time wherever irrigation occurs, since almost all water (even natural rainfall) contains some dissolved salts.

When the plants use the water, the salts are left behind in the soil and eventually begin to accumulate. Since soil salinity makes it more difficult for plants to absorb soil moisture, these salts must be leached out of the plant root zone by applying additional water. This water in excess of plant needs is called the leaching fraction (Grattan, 2002).

Fig.1 Effects of salt stress on fruit plants

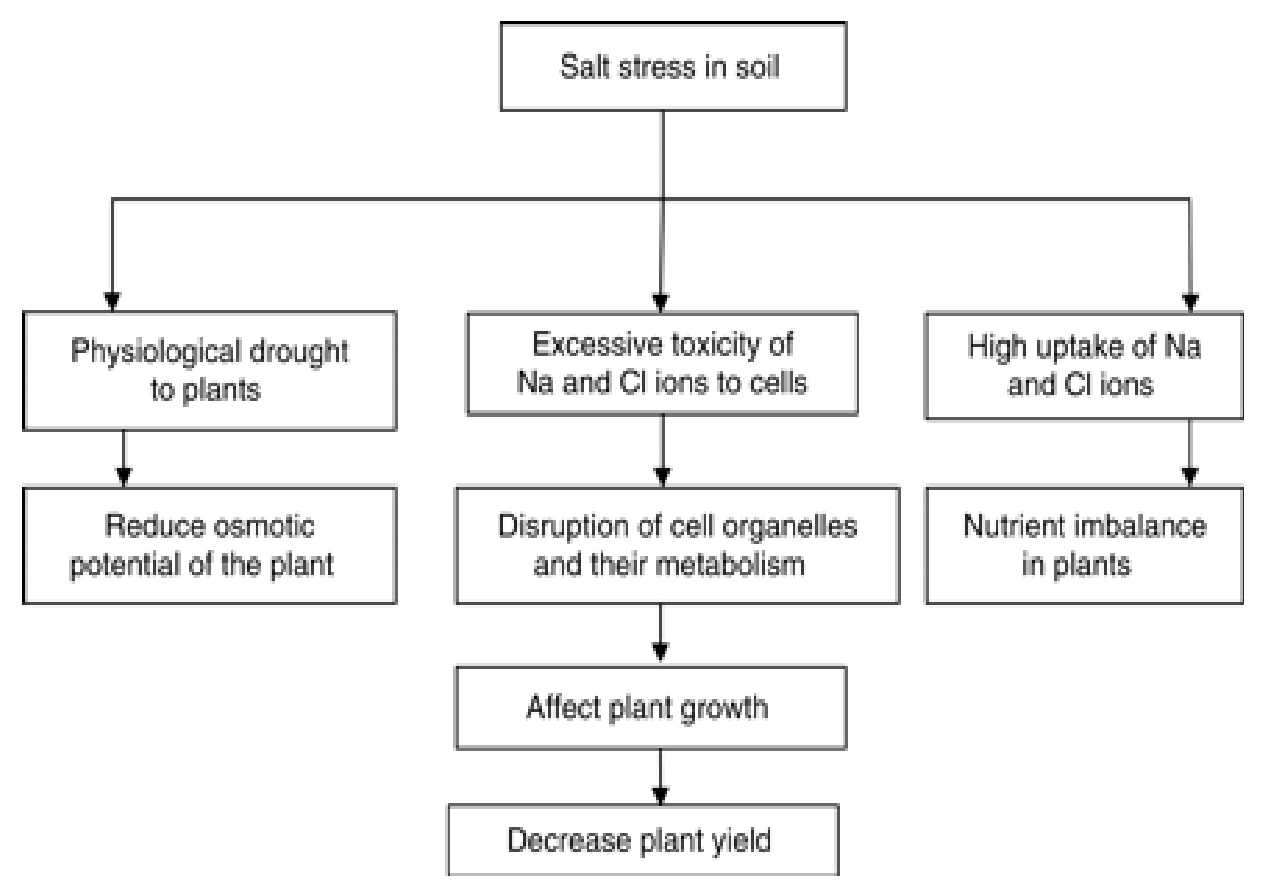

Table.1 Fruit crops tolerant to salinity

\begin{tabular}{|l|l|}
\hline Tolerance level & Fruit crops (Mckersie et al., 1994) \\
\hline Tolerant & Phoenix dactylifera, Emblica officinalis \\
\hline Moderately tolerant & Olea europaea and Ficus spp. \\
\hline Sensitive & Malus domestica, Prunus armeniaca, Prunus domestica, Prunus persica \\
\hline
\end{tabular}


Table.2 Rootstocks for salinity tolerance

\begin{tabular}{|l|l|l|}
\hline Fruit Crops & Rootstock & References \\
\hline Almond & GF677 & (Zrig et al., 2015) \\
\hline Ber & Zizyphus nummularia & (Pareek, 2001) \\
\hline Grape & Dogridge and Salt Creek B-2/56,110R & (Sharma et al., 2011) \\
\hline Mango & Mangifera zeylanica, Gomera-1, 13-1 & (Ravishankar et al.,2012) \\
\hline Citrus & Rangpur lime and Cleopatra mandarin & (Anjum et al., 2008) \\
\hline Annona & Annona diversifolia and Annona reticulata & (Pareek et al., 2011) \\
\hline
\end{tabular}

\section{Tillage}

It is a mechanical operation usually carried out to break the salty layer closer to the root surface.

\section{Mulching}

Soil mulching maintain wet zone in the rhizosphere, salt concentration in root zone gets diluted and the salinity effect on the fruit plants reduced.

\section{Irrigation method}

The irrigation method and volume of water applied have a pronounced influence on salt accumulation and distribution. Flood irrigation and an appropriate leaching fraction generally move salts below the root zone. Similar results can be obtained with a properly managed sprinkler irrigation system. With furrow and pressurised irrigation, soluble salts in the soil move with the wetting front, concentrating at its termination or at its convergence with another wetting front. In drip-irrigated plots, water moves away from the emitter and salts concentrate where the water evaporates.

\section{Fertilizer management}

Many fertilisers contain soluble salts in high concentrations. Therefore, the nutrient source, rate, timing and placement are important considerations in the production of horticultural crops. Salt indices for most commercial fertiliser products have been reported. For example, $\mathrm{KCl}$ has a salt index 205 times that of $\mathrm{K}_{2} \mathrm{SO}_{4}$. Generally, band application of fertilisers with high salt indices near seedlings should be avoided. The salt content of other things added to the soil, such as gypsum and manures, also should be considered. Applying gypsum is a useful management practice for precluding sodium accumulation on the soil's exchange complex, maintaining soil structure and improving water infiltration.

\section{Salt tolerant fruits}

Plant species vary in their responses to saline conditions. While salt-tolerant plants have the ability to cope with a relatively high level of soil salinity, susceptible plants are not able to grow under the same salinity conditions (Munns and Tester, 2008) (Table 1). As in fruit crops Cashew nut (Annacardium occidentale L.) showing some adaptations and acclimations to water deficit, and it has been strongly used as a model to evaluate salt tolerance mechanisms (Marques et al., 2010). Of all fruit crop species, fruit trees, including citrus, are highly salt sensitive (Storey and Walker, 1999).

\section{Biofertilizer application}

Another possible way to relieve or protect plants from saline stress is to inoculate the roots with arbuscular mycorrhizal fungi 
(AMF), which are considered to be important bio-ameliorators for saline soils. This role of AMF was studied by (Navaro et al., 2010) in citrus seedlings inoculated with a mixture of AMF (Rhizofagus irregularis and Funneli formismosseae), which alleviated the negative effect of salt stress. This protective effect or synergic interaction is even better when it is established with salt-tolerant rootstocks. Similarly mycorrhizal symbiosis have been found the ability of salinity tolerance in Carrizo citrange colonized with Glomus intraradices and grape vine plants inoculated with Burkholderia phytofirmans accumulated higher level of proline, and CHOs (Bensalim et al., 1998) (Table 2).

\section{Salinity tolerant rootstocks}

Generally the fruit crops are vegetatively propagated and rootstocks are commonly used where the grafted technique has been applied, the rootstock properties like salinity tolerance can affect the plant response to salinity. Salttolerant rootstocks alleviate the negative effects of stress and protect the plants.

\section{Application of triazole compounds}

Triazole compounds on mitigating stress impacts on different crops by up-regulating proline content and activities of antioxidant enzyme (Sankar et al., 2007).

\section{Use of plant growth regulators}

\section{Grape}

Cultivar Chardonnay cells treated with $10 \mu \mathrm{M}$ putrescine dihydrochloride increased salinity tolerance (Hassan et al., 2010).

\section{Banana}

Adding 0.2 and $0.4 \mathrm{~g} / \mathrm{l}$ potassium humate to rooting medium tends to increase salinity tolerance of banana plantlets (Hassan et al.,
2010) and application of PBZ (1500 mg/l) mitigated the salinity stress (Srivastav et al., 2010).

Thus, salinity inhibition of plant growth is the result of osmotic and ionic effects and the different plant species have developed different mechanisms to cope with these effects. Crop productivity is severely affected by salinity stress. This occurs directly due to the impact of salinity on photosynthesis, respiration, nutrient assimilation, hormonal imbalance, etc. The indirect adverse effect of salinity is enhanced generation of reactive oxygen species in stressed plant which subsequently cause damage to macromolecules such as lipids, proteins, and nucleic acids, and thus, constrain crop productivity. Therefore, to engineer more salttolerant plants, it is important to find out the key components of the plant salt-tolerance network.

\section{References}

Anjum, M.A. 2008. Effect of $\mathrm{NaCl}$ concentrations in irrigation water on growth and polyamine metabolism in two citrus rootstocks with different levels of salinity tolerance. Acta Physiol Plant, 30: 43-52.

Ashraf, M. and Harris, J.C. 2004. Potential biochemical indicators of salinity tolerance in plants. Plant Sci., 166(1): 3-16.

Bensalim, S., Nowak, J. and Asiedu, S.K. 1998. A plant growth promoting rhizobacterium and temperature effects on performance of 18 clones of potato. Am J Potato Res 75: 145-152?

Bernstein, N., Meiri, A. and Zilberstaine, M. 2004. Root Growth of Avocado is More Sensitive to Salinity than Shoot Growth. J. Am. Soc. Hortic. Sci., 129: 188-192.

Grattan, S., Zeng, L., Shannon, M., and Roberts, S. 2002. Rice is more sensitive to salinity than previously 
thought. California Agriculture, 56(6): 189-198.

Grattan, S.R. 2002. Irrigation water salinity and crop production. Oakland: University of California.

Hasegawa, P.M., Bressan, R.A., Zhu, J.K. and Bohnert, H.J. 2005. Plant cellular and molecular responses to high salinity. Annual Review of Plant Physiology and Molecular Biology, 51(1): 463-499.

Hussain, K., Majeed, A., Nawaz, K., Khizar, H.B. and Nisar, M.F. 2009. Effect of different levels of salinity on growthand ion contents of black seeds (Nigella sativa L.). Curr. Res. J. Biol. Sci., 1: 135-138.

Marques, E.C., Freitas, V. S., Bezerra, M. A., Prisco, J. T. and Gomes-Filho, E. 2010. Effects of salt stress on germination, emergence and establishment of dwarfcashew seedling. Revista Ciencia Agronomica., 42(4): 993-999.

Mckersie, B.D. and Yaacov, Y.L. 1994. Salt stress. In Stress and stress coping in cultivated plants. Springer Netherlands, 55-78.

Munns, R. 2002. Comparative physiology of salt and water stress. Plant Cell and Environment. 25(2): 239-250.

Munns, R. and Termaat, A. 1986. Whole plant response to salinity. Aust. J. Plant Physiol., 13: 143-160.

Munns, R., and Tester, M. 2008. Mechanisms of salinity tolerance. Annu. Rev. Plant Biol. 59: 651-81.

Navarro, J.M., Gomez-Gomez, A., PerezPerez, J.G. and Botia, P. 2010. Effect of saline conditions on the maturation process of clementine Clemenules fruits on two different rootstocks. Span. J. Agric. Res., 8: 21-29.

Navarro, J.M., Perez-Tornero, O. and Morte, A. 2014. Alleviation of salt stress in citrus seedlings inoculated with arbuscular mycorrhizal fungi depends on the rootstock salt tolerance. J. Plant
Physiol., 171: 76-85.

Pareek, O.P. 2001. Ber, International Centre for Underutilised crops pub. Southampton, UK.

Pareek, S., Elhadi, M., Pareek, O.P. and Kaushik, R.A. 2011. Postharvest physiology and technology of Annona fruits. Food Research International, 44:1741-1751.

Patane, C., Saita, A. and Sortino, O. 2012. Comparative effects of salt and water stress on seed germination and early embryo growth in two cultivars of sweet sorghum. Journal Agronomy and Crop Science; $1-8$.

Ravishankar, H., Singh, V.K. and Gutam, S. 2012. Evaluation of Salinity Stress Tolerance in Mango (Mangifera indica L.). Genetic Resources-Way Forward.

Romero-Aranda, R., Moya, J.L., Tadeo, F.R., Legaz, F., Primo-Millo, E. and Talon, M. 1998. Physiological and anatomical disturbances induced by chloride salts in sensitive and tolerant citrus: Beneficial and detrimental effects of cations. Plant Cell Environ, 21: 12431253.

Sankar, B., Jaleel, C.A., Manivannan, P., Kishorekumar, A., Somasundaram, R. and Panneerselvam, R. 2007. Drought induced biochemical modifications and proline metabolism in Abelmoschus esculentus (L.) Moench. Acta Bot Croatica, 66: 43-56.

Sharma, J., Upadhyay, A. K., Bande, D. and Patil, S.D. 2011. Susceptibility of Thompson Seedless grapevines raised on different rootstocks to leaf blackening and necrosis under saline irrigation. Journal of plant nutrition, 34(11): 1711-1722.

Srivastav, M., Kishor, A., Dahuja, A. and Sharma, R.R. 2010. Effect of paclobutrazol and salinity on-ion leakage, proline content and activities of antioxidant enzymes in mango 
(Mangifera indica L.). Scientia horticulturae, 125(4): 785-788.

Storey, R. and Walker, R. R. 1998. Citrus and salinity. Scientia Horticulturae, 78(1): 39-81.

Zhao, G.Q., Ma, B.L. and Ren, C.Z. 2007. Growth, gas exchange, chlorophyll fluorescence and ion content of naked oat in response to salinity. Crop Sci., 47 (1): 123-131.
Zrig, A., Tounekti, T., Ennajeh, M., Valero, D. and Khemira, H. 2015. A comparative study of salt tolerance of three almond rootstocks: Contribution of organic and inorganic solutes to osmotic adjustment. Journal of Agricultural Science and Technology, 17(3): 675-689.

\section{How to cite this article:}

Anjali Soni, Sunita Dhakar and Neeraj Kumar. 2017. Mechanisms and Strategies for Improving Salinity Tolerance in Fruit Crops. Int.J.Curr.Microbiol.App.Sci. 6(8): 1917-1924. doi: https://doi.org/10.20546/ijcmas.2017.608.226 